\title{
Handbook of Florida Water Regulation: Florida Lake Okeechobee Protection Act ${ }^{1}$
}

\author{
Michael T. Olexa, Luke D'Isernia, Laura Minton, Dulcy Miller, and Sarah Corbett ${ }^{2}$
}

\section{Preface}

This handbook is designed to provide an accurate, current, and authoritative summary of the principle Federal and Florida laws that directly or indirectly relate to agriculture. This handbook should provide a basic overview of the many rights and responsibilities that farmers and farmland owners have under both Federal and Florida laws as well as the appropriate contact information to obtain more detailed information. However, the reader should be aware that because the laws, administrative rulings, and court decisions on which this handbook is based are subject to constant revision, portions of this publication could become outdated at anytime.

Several details of cited laws are also left out due to space limitations.

This handbook is distributed with the understanding that the authors are not engaged in rendering legal or other professional advice, and the information contained herein should not be regarded as a substitute for professional advice. This handbook is not all inclusive in providing information to achieve compliance with the Federal and Florida laws and regulations governing water protection. For these reasons, the use of these materials by any person constitutes an agreement to hold harmless the authors, the Florida Cooperative Extension Service, the Institute of Food and Agricultural Sciences, and the University of Florida for any liability claims, damages, or expenses that may be incurred by any person as a result of reference to or reliance on the information contained in this handbook.

\section{Overview}

In recognition of Lake Okeechobee's ecological significance and its economic importance to Florida's economy, the Florida Legislature passed the Florida Lake Okeechobee Protection Act (FLOPA) in 2000. Similar to the primary goal of FEFA, the primary goal of FLOPA is to reduce the levels of phosphorus in the Lake Okeechobee Watershed. Another similarity is that both the state legislature and the federal government have recognized that improvement of the hydrology and water quality of Lake Okeechobee is essential to the protection of the

1. This is EDIS document FE610, a publication of the Food and Resource Economics Department, Florida Cooperative Extension Service, Institute of Food and Agricultural Sciences, University of Florida, Gainesville, FL. Published December 2005. Please visit the EDIS website at http://edis.ifas.ufl.edu.

2. Michael T. Olexa, Professor, Food and Resource Economics Department, Florida Cooperative Extension Service, Institute of Food and Agricultural Sciences, University of Florida, Gainesville, FL; Director, Agricultural Law Center, University of Florida, Gainesville, FL; and Chair, Agricultural Law Committee of The Florida Bar. Luke D'Isernia, former student (graduated cum laude in 2005), Levin College of Law, University of Florida, Gainesville, FL. Laura Minton, Attorney, Dean, Mead, Egerton, Bloodworth, Capouano, and Bozarth, Orlando, FL. Dulcy Miller, attorney, Foley and Lardner, LLP, Orlando, FL. Sarah Corbett, Attorney, Florida Second District Court of Appeal, Lakeland, FL.

The Institute of Food and Agricultural Sciences (IFAS) is an Equal Opportunity Institution authorized to provide research, educational information and other services only to individuals and institutions that function with non-discrimination with respect to race, creed, color, religion, age, disability, sex, sexual orientation, marital status, national origin, political opinions or affiliations. U.S. Department of Agriculture, Cooperative Extension Service, University of Florida, IFAS, Florida A. \& M. University Cooperative Extension Program, and Boards of County Commissioners Cooperating. Larry Arrington, Dean 
Everglades. The Lake Okeechobee Water Project (LOWP) restoration is part of the Comprehensive Everglades Restoration Program (CERP), officially known as CERP-LOWP. To carry out the comprehensive goal of reducing phosphates in Lake Okeechobee, FLOPA initiated five separate programs (the Lake Okeechobee Construction Project, the Lake Okeechobee Watershed Phosphorus Control Program, the Lake Okeechobee Research and Water Quality Monitoring Program, the Lake Okeechobee Internal Phosphate Management Program, and the Lake Okeechobee Exotic Species Control Program) to generate the relevant information necessary to propose the Florida Lake Okeechobee Protection Plan (FLOPP), the comprehensive plan which will be instituted to reduce the levels of phosphorus in the Lake Okeechobee Watershed.

Non-point source pollution, especially from agricultural non-point sources, is addressed in FLOPA and FLOPP with the use of best management practices (BMP) and stormwater treatment areas (STA).

\section{Who Enforces FLOPA and FLOPP?}

Under FLOPA and FLOPP, primary enforcement and regulatory power is vested in the Southwest Florida Water Management District (SFWMD), the Department of Environmental Protection (DEP), and the Florida Department of Agriculture and Consumer Services (DACS) to be performed in a cooperative fashion. While each entity is given specific tasks under the FLOPA and FLOPP, they must consult with the other entities to coordinate the regulation and enforcement of FLOPA and FLOPP.

\section{What Are the Duties of SFWMD, DEP, and DACS under FLOPA?}

Under FLOPA, SFWMD is required to implement, design and construct (often in partnership with the Army Corp of Engineers, or ACE) the Lake Okeechobee Construction Project (LOCP), a series of stormwater treatment facilities, reservoirs, and other installations (constructed in priority basins) necessary to treat the waters entering the Lake Okeechobee Watershed in cooperation with the ACE,
DEP and DACS. Every three years the SFWMD, DEP, and DACS are required under FLOPA to evaluate if any further phosphorus load reductions are necessary to achieve compliance with the phosphorus TMDL for Lake Okeechobee. SFWMD is tasked with identifying any modifications to these facilities if the phosphorus TMDL for Lake Okeechobee is not met.

These facilities must be reviewed and commented on by the DEP prior to the execution of a construction contract by the SFWMD for that facility.

Regarding the Lake Okeechobee Watershed Phosphorus Control Program, the SFWMD, DEP, and DACS are required under FLOPA, among other tasks, to enter into an interagency agreement to develop BMPs that complement existing regulatory programs and specifies how those BMPs will be implemented and verified.

In dealing with agricultural non-point source pollution, the DACS, in consultation with SFWMD and DEP, is required to initiate rule development for temporary measures, BMPs, conservation plans, nutrient management plans, and other measures necessary for the Lake Okeechobee phosphorus load reduction. DACS is further tasked with conducting an ongoing program for improvement of existing and development of new agricultural non-point source BMPs. Also DACS, in cooperation with SFWMD and DEP, must provide technical and financial assistance for implementating agricultural BMPS. The SFWMD and DEP must conduct monitoring to verify the effectiveness of agricultural non-point source BMPs.

The DEP is also required to coordinate and provide assistance to local governments seeking financial assistance for projects which reduce the phosphorus load originating from domestic wastewater systems within the Lake Okeechobee watershed.

Under FLOPA, the SFWMD, DACS, and DEP are required to establish the Lake Okeechobee Research and Water Quality Monitoring Program, which will:

- Develop a Lake Okeechobee water quality model that reasonably represents phosphorus 
dynamics of the lake and incorporates an uncertainty analysis associated with model predictions.

- Determine the relative contribution of phosphorus from all identifiable sources and all primary and secondary land uses

- Assess current water management practices within the Lake Okeechobee Watershed and develop recommendations for improvements.

In the Lake Okeechobee Internal Phosphate Management Program, the SFWMD, DEP and DACS are required under FLOPA to complete a Lake Okeechobee internal phosphorus removal study to address all reasonable methods of phosphorus removal. If any feasible methods are found, the SFWMD must pursue the design, funding, and permitting required to implement the methods.

In the Lake Okeechobee Exotic Species Control Program, the SFWMD, DEP, and DACS are tasked with identifying exotic species that threaten native species within the Lake Okeechobee Watershed and develop and implement measures to protect those native species.

For more information on the requirements of the SFWMD, DEP, and DACS under FLOPA, please contact these agencies.

\section{What Are the Duties of SFWMD, DEP, and DACS under FLOPP?}

The roles and duties that SFWMD, DEP, and DACS had under FLOPA are maintained under FLOPP. Along with continuing the collection of data under the FLOPA programs and applying that data in the implementation, modification, and enforcement of FLOPP, these agencies are also continuing their work in designing and constructing the stormwater treatment facilities under the LOCP. The DEP enjoys new responsibilities, including the enforcement of NPDES permits for confined animal feeding operations (CAFO).

The FLOPP, chosen to reduce the level of phosphorus in the Lake Okeechobee watershed to met the 140 metric ton TMDL for phosphorus of the watershed, has the following components: owner implemented BMPs (primarily operational changes), cost-share BMPs (primarily structural changes), and regional projects outside of CERP. However, the majority of the load reductions are to be met through the regional solutions contained in the CERP-LOWP.

Under the Lake Okeechobee Protection Plan, farmers are expected to implement cost-sharing BMPs to reduce the level of phosphorus in the Lake Okeechobee Watershed. BMPs for each farm will be identified through an assessment performed by the DACS and nutrient management plans through USDA-NRCS. Examples include internal fencing to keep cows out of wetlands and streams, onsite retention facilities, and/or a storm water management system.

Farmers that do not take part in these BMPs will be required to monitor the levels of phosphorus leaving their property and entering the watershed to ensure that the TMDL of phosphorus for the watershed is met. The levels of phosphorus leaving these properties will also be monitored and verified by the SFWMD and DEP. If the phosphorus TMDL is not met and it is determined that it is due to phosphorus from these properties, the farmers will be sanctioned by the SFWMD accordingly.

Homeowners and municipalities are expected to implement owner-implemented BMPs that are economically and technologically feasible. Regional treatment will then be used to address the remaining phosphorus load reduction. These include reducing phosphorus fertilization and implementing other lawn BMPs such as buffers between water bodies and fertilizer application, the timing of fertilizer applications, irrigation practices, etc.

The next step will be the implementation of typical cost-share BMPs, such as retrofitting municipal stormwater sewer systems in the watershed area to further reduce the phosphorus load in the watershed.

Regional projects outside of CERP include the expansion of the Nubbin Slough pilot storm water treatment area (STA) to include a reservoir and larger STA on land owned by the SFWMD, the connection of septic tanks and wastewater treatment plants to a 
regional treatment facility, and the facilities constructed under CERP.

The CERP-LOWP conceptual plans consist of the construction of STAs and reservoirs, restoration of wetlands, and removal of phosphorus laden sediment from tributaries. Implementation of CERP-LOWP is a 50/50 partnership between the SFWMD and ACE. The planning process will be documented in a Project Implementation Report (PIR) that will be integrated with an EIS, this is scheduled to be released for public review in March 2006. There are ten initial authorized projects in CERP-LOWP, including the Taylor Creek/Nubbin Slough Reservoir and Treatment Area Project (TCNS) which, although land has been purchased by the SFWMD, it is still in the planning phase. The remaining CERP-LOWP projects must be authorized by the United States Congress which will be authorized in the Water Resources Development Act of 2008. Construction of the TCNS project is scheduled to be completed by July 2011.

For more information on FLOPP, visit online at http://www.dep.state.fl.us/water/wqssp/

lakeo_pplan.htm.

\section{Source}

Chapter 373, Florida Statutes, Sections 373.451 to 373.459 and 373.4595

\section{Acknowledgments}

The authors are indebted to the personnel of both state and federal agencies who provided their time and advice in the preparation of this handbook. The authors are especially indebted to Richard Budell of the Office of Agricultural Water Policy of the Florida Department of Agriculture and Consumer Services for providing funds for the development of this publication. 